\title{
THE CONFLUENCE OF RHETORIC AND ETHICS IN HURTING THE TEXT, WITH FOCUSING ON PIECES OF ANVARI POETRY (DIWAN)
}

\author{
M. J. Erfani Beyzaei ${ }^{1, *}$, A. A. Barsar Amad ${ }^{2}$ \\ ${ }^{1}$ Assistant Professor in Persian language and literature of Payamenoor University \\ ${ }^{2}$ Holding Master's degree in Persian Language \& Literature of Payamenoor University
}

Published online: 18 July 2016

\begin{abstract}
Ethics (morality) is the detecting excellences and achieving them and recognizing vices and avoiding or releasing them. Whatever is in line with these two things, called morality? Rhetoric is the expressiveness of language which is resulted from observing principles and rules of a collection of innovative science, meaning and expression. Observing addressee status in semantics as a part of rhetoric has aspects that observing cultural-ethical standards which are respectful for addressee is one of its components. Anvari Abiverdi was the poet of $6^{\text {th }}$ century who has experienced composing poems in various kinds of framework. While Anvari is mostly known for his odes which are often eulogy. However the power of Anvari in poetry is so popular but his failure in observing border and entering to taboo hurt his poetry through 2 ways: first they make addressee to turn away toward the text and second the editor is forced to manipulate the main text and remove some part of it. This is a point which rhetoric principles and ethical standards confluence and they act against the text with a common position.
\end{abstract}

\footnotetext{
Author Correspondence, e-mail: M_erfani@pnu.ac.ir

doi: http://dx.doi.org/10.4314/jfas.v8i2s.131
} 
Studying, understanding and introducing this confluence point would open a new window to studying literary texts.

Keywords: ethics, rhetoric, addressee status, Anvari, pieces

\section{INTRODUCTION}

Rhetoric is the expressiveness of speech that this expressiveness is a notion which is studied in semantics and of elements which creates speech according to addressee status. Speech according to addressee status has aspects that observing cultural-ethical standards which are respectful for addressee is one of its components.

Here in addition to optional selection of the addressee, sometimes ethical-cultural standards become so decision-making that in the case of not observing borders and specially entering taboos, it would either make reader disappointed toward the text or make the editor manipulate the main text and remove some part of it. This is the point in which rhetoric principles and ethical standards confluence, and with a common position acts against the text.This study aimed to introduce the damages to the text of Anvari pieces due to not observing the importance of addressee status and ethical standards of target population (specially about verbal and thematic taboos), indicates the confluence point of rhetoric criticism and ethical criticism and the companionship of these two against the text which is indifferent toward the addressee status and ethical standards.

Questions of the study include: what is the relationship between rhetorical criticism and literary criticism? What are the addressee needs in Anvari poetry generally? What is the general position of addressee of Anvari poetry toward ethical taboos? were addressee needs and ethical standards observed in Anvari poetry?

For answering the questions of study about rhetorical criticism, it was focused on semantics and also proposed ethical criticism, then with showing the existence of relationship between rhetoric and ethic we answer the question of the study.

\section{Analysis}

Literature review: Anvari is one of the popular Persian poets and many studies have been conducted about him and his works. In about all of editions on Anvari diwan, there are some critiques about his poetry (specially his pieces). In addition, various articles have been written in this area which have focused on his diwan and specially odes from different views. Some of 
them include Atashkade Azar (Azar Bigdeli:1337), Alajam fi Maa'yer, Alajar poetry (Razi:1338), Tazakreh Alshoara (Saramqandi:1338), Mofles Kimia Forush (Shafiee Kadkani:1389) and etc

Anvari: Mohammad ibn Ali Alanvari. Was the poet of $6^{\text {th }}$ century who was familiar with math, astronomy, logics, philosophy, medicine and natural sciences, Arabic literature and in some fields he had written some works. He was born in a small village of Abivard region called "Bazan". However his exact birth date is not known. He was apparently muslim. Anvari was a free-living and jovial boy, he had missed his father's heritage.His confess about having disease of wealthy and noble people e.i gout is thinkable. But what important for us about his life is that after wasting his father's heritage and becoming poor, he helplessly became poet and Panegyrist of kings (Seyed jafar hosseini: 1382) in explaining problems of Anvari diwan, Moddaares Razavi named 70 people as panegyrists of Anvari (Madders razavi:1340/ 37-90). Shafiee Kadkani confirmed this in Mofles kimia forush (Shafie kadkani: 1390,28). These panegyrists are mainly governors, officials or his family.

Anvari: he wrote poetry in frames of ode, piece, lyrics, and quatrain but his popularity is mostly because of his odes. .

Anvari pieces: in edition of Madarres razavi, the second part of Anvari diwan was written in pieces by this poet. The number of these pieces in thisedition is about 492 .

Rhetorical criticism: is a practical critique which its subject is to review the effect of literary works on reader or listener. Rhetorical criticism attracts the energy of the addressee more than everything to have some effects as enjoying, teaching, changing moral orientations and etc. However by the greatest effect we mean to meet the objective of producing text (not every effect). By interpreting of Sirus Shamsia, this kind of criticism analyzes elements that the creator tries to impose his view on reader with them. (Shamsia:1383:37)

Rhetoric and respect for the spiritual needs: after eloquence, rhetoric (correct speech) means to infer and has three components: Exquisite, expression and meaning (semantic). Exquisite (novel) is innovations which orator uses in his speech. Expression is to take lecture with imagination and the most important aspect of semantics is too speak with considering position needs, subject and position of addressee in a way that becomes effective. 
However many Rhetoricians considers the main base of semantics on four forms: statement, question, imperative, emotional. But semantics had history dating back to Aristotle history (in Rhetoric book), has another valuable sentence which results from position needs.

Ethical criticism: ethic is a queen that make ego needless of thinking and visibility (Toosi, 1391:6). In other words, morality is the recognition of virtues and achieving them and recognition of vices and avoiding or releasing them. Whatever is in line with these two is called ethics. (Sharifi,N.k, 1386: volume 2, below of good ethic, bad ethic)

Ethical criticism has been often paid attention by religious teachings. Thus they knew works in contrast to religious teaching as in opposition to ethic and considered as bad. Since in civil societies, ethic is generally formed based on religion" (Nosrati: 1391: 80-90). Therefore criticism that includes mentioned issues is called ethical criticism.

"Taboo is a forbidden territory and its failure causes misfortune (Shamsia, 1383: 244). Taboo is one of components of ethical issues which is referred to a series of words or expressions which is considered bad in public and is avoided to express them.

Cultural-ethical principles of readers' society and literary self-criticism: one of the components which is sometimes neglected and provides some unwanted effects and sometimes has good effects. Creator of the work should know that who uses his work.

in another word, the creator should have a clear image in his mind from the customer of his cultural works, therefore he set the work according to his culture and ethical principles of readers' society. Actually this work is a kind of "self-criticism" during production of the work (Nosrati, 1393: 7993). He should remove words and expressions which he knows as taboo and unsuitable for cultural needs of the addressee.

The value of poem and poetry to readers' society of Anvari pieces: one of the ethical criticism aspects is to focus on author's view and performance toward his society's values. The degree of poem and poetry is paid attention from at least two perspectives: first what is and was the status of poem and poetry in Islam and Iran? And how would poets such as Anvari rate poem and poetry?After Islam and regarding this matter that Islam pays attention too much to "word" and "pen" (writing), the status of poets and also poem increased. Gold swears to pen and whatever that writes (Quran, 1389. Sura69, verse1). The effects of this work are undeniable in narratives. On the other hand, poetry has been important for Iranian. Diwan of poets such as Ferdowsi, 
Nezami, Rumi, Attar, Baba Afzal and etc are proof for this claim. So this is natural that such a society of readers is sensitive toward content of poetry.

Poetry for Anvari: Anvari uses the god gift of poetry to earn money and position. He wrote with pen (that god swears to it) and quit politeness and admired his panegyrists by entering areas of idolatry and blasphemy to provide grass and hay for his donkey and horse and his own food and clothes. He wrote poem to earn money to take a bath and etc. He called poetry "menstruation of men".

Dignities of poetry in Anvari pieces: for society of Anvari readers, poet is the heir of wisdom and brightness. He is helpful and continuer of the way of those who were raised for guiding mankind from god side. Also for these addresses, every human should appreciate his own soul-mate and human soul-mate beyond poetry. Human being is the elite of creatures.

To poet as Anvari, those who grant hay and shoes to other or allow him to their house has a high dignity more than sky. So it is natural that if someone does not give him hay, if Anvari can, he insults them, if not, he would call himself ass! Which is not desirable neither for morality of reader's society nor for position status from rhetoric view.

Ethical-cultural taboos in Anvari pieces: Anvari has no respect for his addresses in satire and wisecrack, while these ethical criteria through status needs have relationship with rhetoric. $\mathrm{He}$ used vulgar words recklessly which every eloquent orator avoids using them and calls them taboo. He wrote poem to make his lords, who are rich, laugh and earn money and wage. However he himself confesses that this is tomfooler

His impoliteness hurts the first damage to his poetry. In some examples we observe that the editor (or the publisher) does not permit himself to use this impoliteness toward addresses. Thus we see three dots instead of a word or phrase which itself hurt the text:

Safi MohammadTarikhi, Afraid of god and stay home and do not come out that people may call you shit ...

Thousand ... donkey in ... woman of that tribe (Anvari: 525)

In a preliminary review, we can categorize obscene words and concepts of Anvari diwan in 3 groups. These three groups in lyrics, odes, pieces and quatrain are shown in table 1.

There is no clear criterion for recognizing obscene words and concepts and this can be different from culture to culture and even from person to person. Therefore the effect of researcher's view on statistics is inevitable, but it is tried to consider some points that are more general according 
to the researcher. It can be said that lyrics are the most cleanest and pieces are the most polluted form in Anvari diwan.

Table 1.

\begin{tabular}{|l|l|l|l|}
\hline $\begin{array}{l}\text { Form } \\
\text { /case }\end{array}$ & $\begin{array}{l}\text { Vulgar } \\
\text { concept or } \\
\text { word }\end{array}$ & Insult & $\begin{array}{l}\text { Inexpressible } \\
\text { concepts }\end{array}$ \\
\hline Lyric & & & \\
\hline Ode & & & \\
\hline Pieces & & & \\
\hline Quatrain & & & \\
\hline total & & & \\
\hline
\end{tabular}

Using taboos is a point which rhetoric and ethic confluence and both of them reject the text in which there are vulgar and offensive words and phrases. In other words rhetoric orders the poet what to say according to addressee's needs and on other hand ethic orders that the poet should not use impoliteness and since ethic usually related to the ideology of the society, it also helps ethics to order that not apply these kinds of offensive words for addressees.

The other evidences which shows unimportance of politeness in cultural-ethical components for Anvari that its result is not respecting addressee's needs, his view toward women, family and marriage. However this discussion has a position in social criticism, but we can consider it from ethical view.

Exactly in contrast to his addressee's morality, he has an unbeautiful look toward woman and he not only does not release the basis of family, but also encourages married people to get divorce. Family is sacred in culture of addressee of Anvari's poetry and insulting it is obscene by view of majority of them. It is natural that the reader of these poems would not support this kind of poetry that has this view toward woman.

\section{CONCLUSION}

The addressees of Anvari poetry include people who has ancient and powerful cultural-ethical root. Since in semantic discussions, the important aspect of rhetorical basis of a text is to respect addressee's needs, it is necessary for a poet to pay attention to it. From addressee's view of Persian poetry especially Iranian, one of the most important aspects of respecting addressee's needs is to observe politeness and avoiding using vulgar words and taboos. On the other hand poets in Iran culture are prominent people of the society which god grants blessing of broad 
vision and openness language to use them at the service of culture and ethic of society. Thus for reader of Persian poetry, every impoliteness toward position of poets and poetry is forbidden and no addressee like these things, but as soon as he recognizes this matter he would become reluctant and won't continue reading or hearing it.

Avnvari pieces do not pay attention to these matters. The position and importance of poet and poetry for addressee is no important for Anvari. He does not appreciate his position. Rhetoric and ethic order that the Persian poet should respect his own position but Anvari adulates, sales poetry for providing grass of his donkey, money of bathing or clothes. Thus he destroys respecting woman and family, religious respects and cultural principles of the addressees and then he himself and his poetry insults the poet and poetry. Therefore the reader should withdraw reading it or the editor should help the text and by using the existing tool and particularly deleting and using dots instead of words and phrases reduces the offensive aspects of the text. But this action wanted or unwanted hurt the text.

\section{REFERENCES:}

\section{Books}

1- Holy quran, 1389 , translation and explanation of selected verse: naser makarem shirazi, $2^{\text {nd }}$ edition, nashta

2- Azar bigdeli, lotf ali beik, 1337, atashkadeh azar, woth effort of seyed jafar shahidi, Tehran, ketab

3- Brown, Edward, 1358, diba history of iran, translated by pasha saleh, Tehran: amir kabir

4- Hosseini farahani, morza abolhassan and modarres razavi, seyed mohammad taqi, 1372, explanation of problems of Anvari diwan: Tehran. Tehran university

5- Razi, shamsoddin mohammad ibn qeis, 1338, alajam fo mayer poetry of alajam, edition by mohammad qazivini and opposition of modarres razavi, Tehran, Tehran university

6- Samrqandi, dowlatshah, 1338, tazkarato alshoara, with effort of mohammad ramezani, Tehran, kalaleh khavar

7- Sharifi hossein, 1386, children and young children encyclopedia, Tehran: children and young children encyclopedia

8- Shafiee kadkani, mohammad reza, 1389, mofles kimia forush, Tehran, sokhan

9- Shamisa sirus, 1383 , literary criticism, $4^{\text {th }}$ edition, Tehran: mitra 
10- Shahidi, seyed jafar 1350, Madiha evolution of writing in Persian literature, $6^{\text {th }}$ century, nameh minoo, Tehran: sanaee

11- 1383 explanation of words and problems of Anvari diwan, Tehran, scientific cultural

12-Safa, zabihollah 1339, history of literature in iran, volume 2, Tehran: ibn sina

13- Toosi, khajeh nasirolddin, 1391, naseri ethic, Tehran, iqbal

14- Nosrati mehrdad, 1393, introduction of self-criticism, as a new and systematic method in studying beyond criticism of literature and art, magazine of electronic, conference of Persian language and literature, bojnord, pp $7983-7995$

15- Vaez kashani, kamaloddin hossein, 1977, badaye fi sanaye alashar, Moscow, danesh

16- Homaee, ostad jalal oddin 1389, Rhetorical Techniques and literary figures, Tehran, ahoora

How to cite this article:

Erfani Beyzaei J M, Barsar Amad A A. The confluence of rhetoric and ethics in hurting the text, with focusing on pieces of anvari poetry (diwan). J. Fundam. Appl. Sci., 2016, 8(2S), 1900-1907. 